\title{
PERIODIG SURGE ORIGIN OF FOLDED MEDIAL MORAINES ON BERING PIEDMONT GLACIER, ALASKA*
}

\author{
By Austin Post \\ (U.S. Geological Survey, Tacoma, Washington 98402 , U.S.A.)
}

\begin{abstract}
Aвstract. The vast Bering piedmont glacier, which has large folds in the medial moraines in its terminal lobe, recently experienced two surges with a combined ice displacement of as much as $13 \mathrm{~km}$. Vertical aerial photographs taken before and after the surges disclose the direction and magnitude of ice flow in various parts of the piedmont lobe. The ice moved toward the terminus and expanded in a normal, radial pattern with no evidence of unusual shearing that would result in the formation of large folds. Many surging glaciers display repeated lateral displacements in their medial moraines which result from periodic surging of the main glacier past non-surging tributaries. Moraines of Bering Glacier display small periodic irregularities of this nature. The large "accordion" folds in the moraines in the piedmont lobe are judged to be due to the combined effects of compressive flow and lateral or transverse expansion of these previously formed irregularities. The initially small pre-existing perturbations in the moraines are simply spread laterally and shortened radially into large folds as the ice spreads out.

A very large debris band composed of repeatedly folded medial moraines extends across the center of the Bering Glacier lobe. These remarkable folds are thought to result from the deformation of surge-related irregularities in medial moraines as they pass through the zone of intensive shear near the glacier's margin.

RÉsumé. Des foirages périodiques a l'origine des ondulations des moraines médianes sur le glacier de Piedmont de Bering, Alaska. Le vaste glacier de Piedmont de Bering qui présente dans ses lobes terminaux de larges ondulations de la moraine médiane, a subi récemment deux foirages ayant donné lieu à un déplacement de glace atteignant ${ }_{1} 3 \mathrm{~km}$. Des photos aériennes verticales prises avant et après les foirages révèlent la direction et la grandeur du courant de glace en différentes parties du lobe de Piedmont. La glace s'est déplacée en avant du terminus et s'est étalée normalement en rayonnant sans qu'il apparaisse un décrochement inhabituel qui aboutirait à former de larges moutonnements. Beaucoup de glaciers sujets à des foirages montrent des déplacements latéraux successifs de leurs moraines médianes qui résultent de foirages périodiques du glacier principal après des affluents sans crue. Les moraines du Glacier de Bering montrent de petites irrégularités périodiques de cette nature. L.es larges ondulations "en accordéon" dans les moraines du lobe de Piedmont sont dûes, pense-t-on, aux effets combinés de la pression du flux de glace es de l'expansion latérale ou transversale de ces irrégularités anciennement formées. Les perturbations préexistantes dans la moraine, d'abord petites, sont étalées, latéralement et raccourcies radialement en larges ondulations pendant que la glace s'étale.
\end{abstract}

Une très large bande de débris composée de moraines médianes à ondulations répétées s'étend à travers le centre du lobe du glacier de Bering. On pense que ces remarquables ondulations résultent de la déformation d'irrégularités de la moraine médiane dûes à des foirages, à leur passage dans la zone d'intense cisaillement près de la rive du glacier.

Zusammenfassung. Periodische Ausbrüche als Anlass für die Faltung von Mittelmoränen auf dem Bering-PiedmontGletscher, Alaska. Der gewaltige Bering-Piedmont-Gletscher, der grosse Faltungen in der Mittelmoräne auf seinem Zungenlobus aufweist, vollführte in jüngster Zeit zwei Ausbrüche mit einer Eisverlagerung von bis zu $13 \mathrm{~km}$. Senkrechte Luftbilder des Zustandes vor und nach den Ausbrüchen lassen die Richtung und Grösse des Eisflusses in verschiedenen Teilen des Piedmontlobus erkennen. Das Eis bewegte sich zum Zungenende und breitete sich in einem normalen, radialen Strömungsmuster ohne ersichtliche ungewöhnliche Scherung, welche die Bildung grosser Falten zur Folge hätte, aus. Viele ausbrechende Gletscher zeigen wiederholt seitliche Verschiebungen ihrer Mittelmoränen, die von periodischen Ausbrüchen des Hauptgletschers an nichtausbrechenden Seitenströmen vorbei herrühren. Die Moränen des Bering-Gletschers zeigen kleine periodische Unregelmässigkeiten dieser Art. Die grossen "Zieharmonika"-Falten der Moränen des Piedmontlobus werden als eine gemeinsame Auswirkung kompressiven Fliessens und seitlicher oder transversaler Ausbreitung dieser vorher gebildeten Unregelmässigkeiten erklärt. Die ursprünglich kleinen, vorgebildeten Störungen in den Moränen werden einfach seitlich ausgebreitet und radial zu grossen Falten verkürzt, wenn das Eis auseinanderfliesst.

Ein sehr grosses Schuttband aus wiederholt gefalteten Mittelmoränen erstreckt sich über die Mitte des Bering-Gletscher-Lobus. Es wird angenommen, dass diese bemerkenswerten Falten durch die Deformation von ausbruchabhängigen Unregelmässikeiten in den Mittelmoränen bei der Durchquerung der Zone intensiver Scherung nahe am Gletscherrand entstanden sind.

\section{SetTing}

The mountain ranges bordering the Gulf of Alaska contain the most extensive icefields on the North American continent. The largest of the glaciers on the coastal side of the ranges generally end in tide water, but in the northern part of the gulf a coastal plain separates the

* Publication authorized by the Director, U.S. Geological Survey. 
mountains from the sea and here are located two very large piedmont glaciers-Bering and Malaspina Glaciers.

Best known is Malaspina Glacier, which covers $2200 \mathrm{~km}^{2}$. Bering Glacier (Fig. I) has a smaller piedmont lobe, but including a broad valley section $50 \mathrm{~km}$ in length has a nearly equal ablation area $\left(2 \mathrm{I} 40 \mathrm{~km}^{2}\right)$. The accumulation area, covering approximately $366 \mathrm{~km}^{2}$, comprises the central part of the Bagley Icefield. Exact area measurement is complicated because the glacier has three north-flowing distributary arms, including the large Tana Glacier. Omitting these distributaries and the part of the icefield judged to supply them, Bering Glacier has a total area of about $5800 \mathrm{~km}^{2}$ (Fig. I).

The accumulation area ratio (Meier and Post, I962, p. 70-74) of Bering Glacier is o.63. Considering that $500 \mathrm{~km}^{2}$ of the ablation area is covered by thick ablation moraine which greatly reduces its melting, this ratio suggests that Bering Glacier is a fairly healthy glacier under present climatic conditions.

The large terminal lobe of Bering Glacier can be conveniently divided into three sections. On the north-west is an area of active, debris-free ice derived from Steller Glacier. The terminus of this part has retreated $3-5 \mathrm{~km}$ from tree-covered terminal moraines, described as "recent" by Miller ( $196 \mathrm{I}$ ). No large-scale folding or unusual flow characteristics of Steller Glacier are evident. The discussions following do not pertain to the ice in this part of Bering Glacier.

The central and south-western part of the terminal lobe, situated between the Khitrof Hills and the terminus, consists of a broad area of ice covered with ablation moraine composed of many intricately folded medial moraines. The ice in this part is essentially stagnant. Its features will be discussed later.

The south-eastern and southern part of the lobe-the largest unit-is supplied from relatively clean ice derived from the Bagley Icefield. This part of the lobe is subject to alternate advances and retreats judged to be due to periodic surges.

\section{FOLDED MORAINES}

The spectacular folded medial moraines on the Malaspina piedmont glacier have long puzzled glaciologists. These structures have been compared to folding in rocks (Carey, 1962), and attempts to simulate their formation have been made in the laboratory (Ramberg, 1964). Washburn and Goldthwait (1936) were first to describe the folds in detail and suggested that they were due to random velocity changes in the glacier's tributaries. Sharp (1958) and Ramberg ( 1964 ) proposed that folding in the form of random crumpling takes place where the ice in the piedmont lobe of Malaspina Glacier is subject to strong compressive flow. In the time Malaspina Glacier has been under detailed observation insufficient movement has occurred to check these hypotheses.

Folded medial moraines are also present on Bering Glacier. The relatively clean eastern part of the Bering Glacier lobe displays a series of faint medial bands composed of fine rock debris, presumed from their position to be derived from tributaries situated near the Canadian border (Fig. I). The pattern formed by the bands suggests that the ice in which they are inset has been deformed into a series of large, fairly regular "accordion" folds.

The structures are not random features unrelated to each other but are composed of a series of major folds with very similar large-scale zig-zag patterns occurring in each medial band. This suggests that the direction of ice flow had been alternately directed toward the left and right sides of the glacier as a unit (Fig. 2).

\section{Recent surges and ice displacements in Bering Glacier}

Bering Glacier has recently experienced two surges with combined ice displacements of as much as $13 \mathrm{~km}$ taking place in the terminal lobe. A major surge, affecting all of the main 


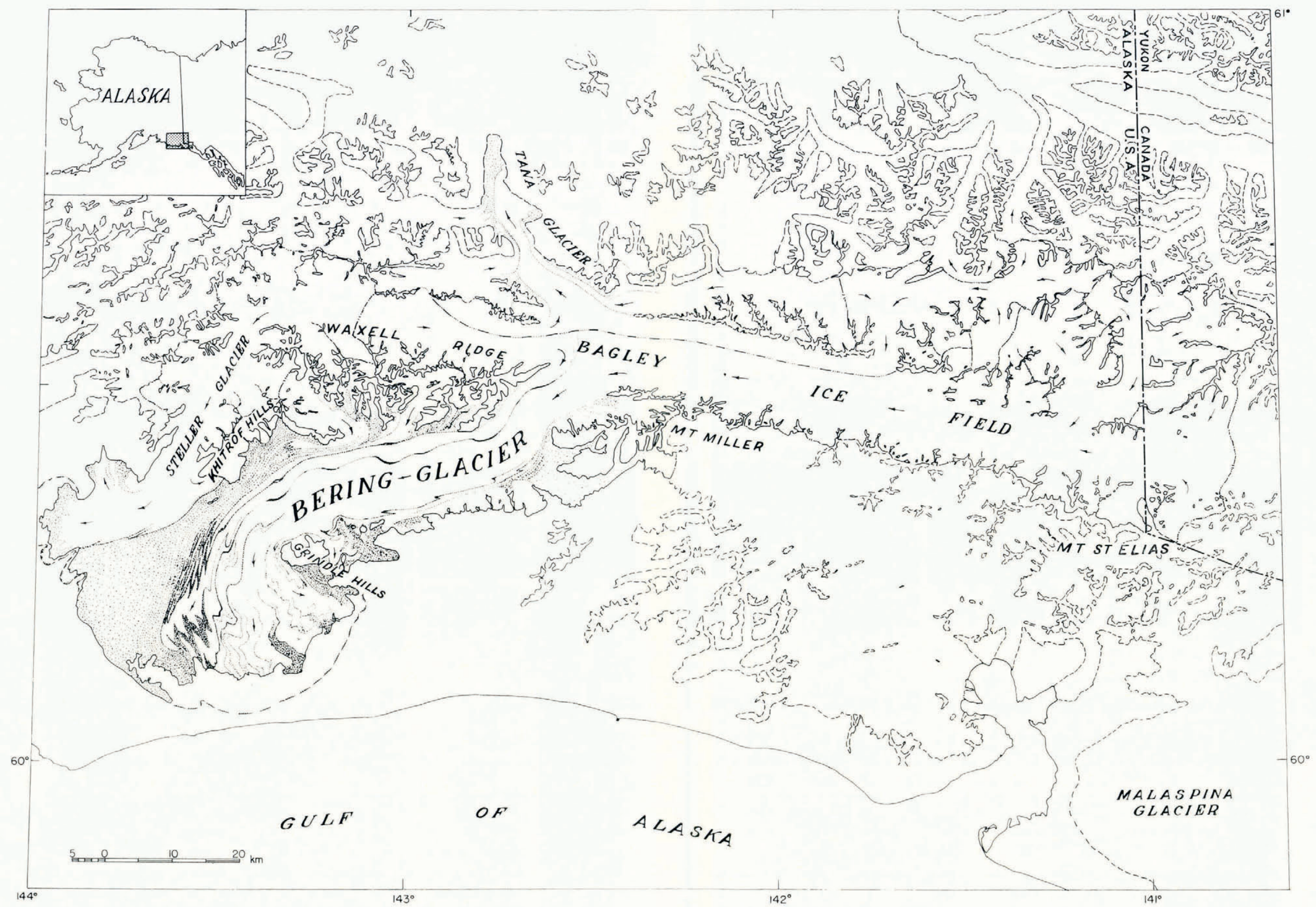

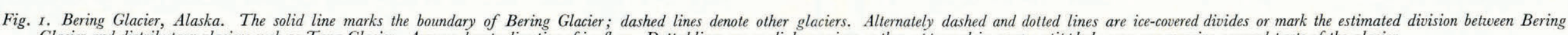

Glacier and distributary glaciers such as Tana Glacier. Arrows denote direction of ice flow. Dotted lines are medial moraines as they appeared in $1957 ;$ stippled areas are moraine-covered parts of the glacier.
The principal accumulation area of Bering Glacier is situated north and north-west of Mount St Elias. The firn line is located north of Mount Miller. Another very large accumulation area is situated north of Waxell Ridge. Nine quite uniformly spaced irregularities are present in the medial moraine derived from this branch. Each of these irregularities is interpreted to result from a surge of the main glacier past this non-surging tributary (see text). [ facing p. 220 
glacier with the exception of a few tributaries, took place between I957 and r96o (Post, I969). Ice flow of as much as $9 \mathrm{~km}$ between these two dates was demonstrated by the displacement of identifiable surface features. A much smaller surge occurred between r 965 and ig66. Further displacements up to $4 \mathrm{~km}$ occurred at this time.

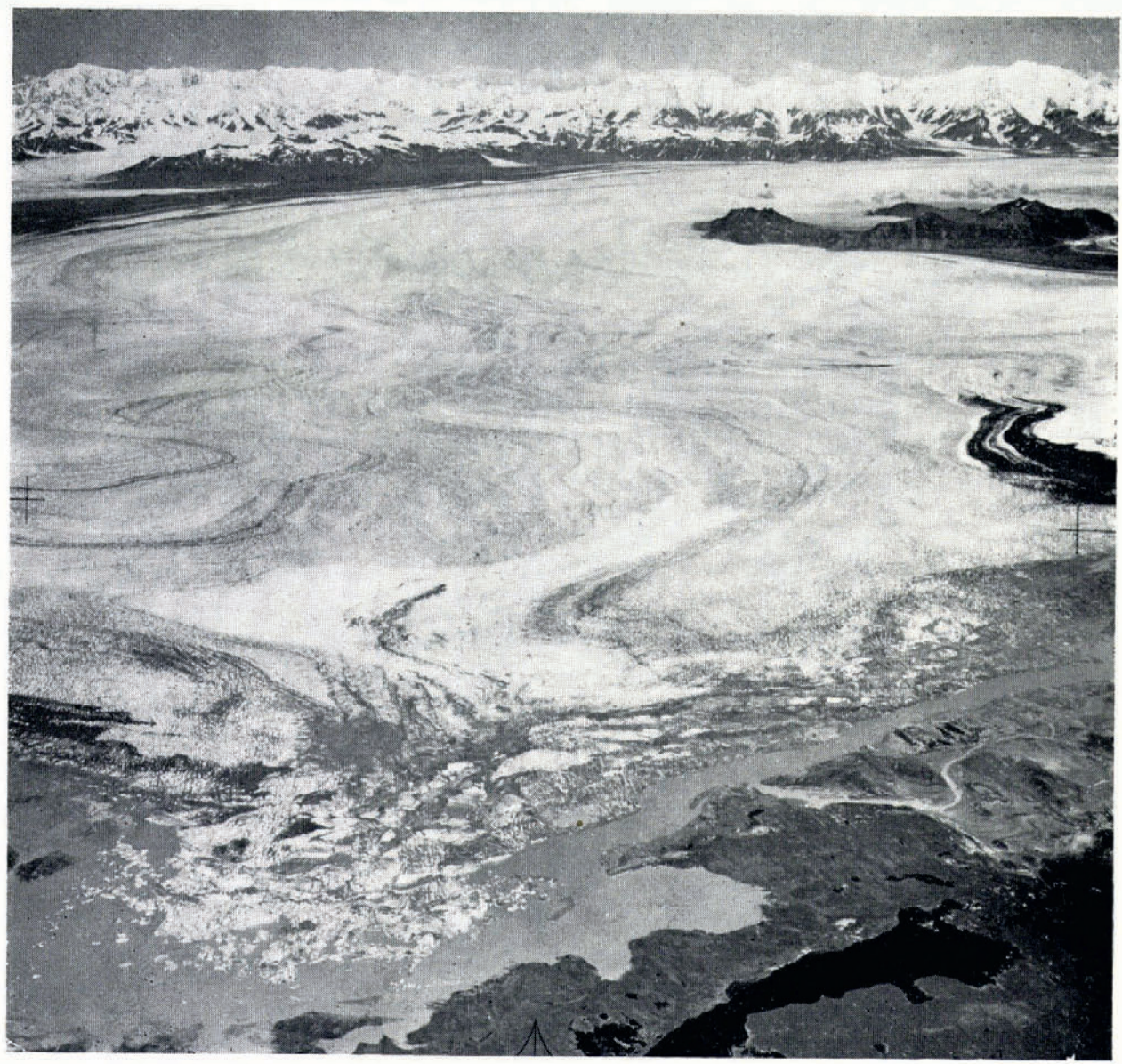

Fig. 2. View north-east from the south margin of Bering Glacier showing the vast expanse of severely crevassed ice in the terminal lobe as it appeared during the 1957-6o surge. Grindle Hills are in the middle distance; Waxell Ridge, culminating in Mount Steller $(3236 \mathrm{~m})$ is on the horizon. The extent of ice affected by this surge was larger in area than all the glaciers of the Alps combined. In the foreground a large, near sea-level marginal lake has been nearly filled by the glacier which advanced over an area of $52.1 \mathrm{~km}^{2}$ during the $1957-60$ surge (Fig. 4). Folded medial moraines can be seen faintly. By ${ }_{196} 6_{3}$, when the severely broken surface ice had melted, these features were much more conspicuous. (Photograph by Austin Post, 25 August 196o.)

Vertical aerial photographs were taken of Bering Glacier in 1957, 1963 and 1967. Using these photographs and detailed I : 48 ooo topographic compilation sheets as a base, the surface features were mapped for these years (Fig. 3). By superimposing these maps, the displacements of the moraines were plotted and movement vectors drawn showing the direction and distance the features had moved (Fig. 4). These vectors disclose that a remarkably uniform, radiating pattern of flow toward the lobate terminus took place during each of the two surges. Clearly, no large-scale buckling occurred in the piedmont lobe which would form folds. 

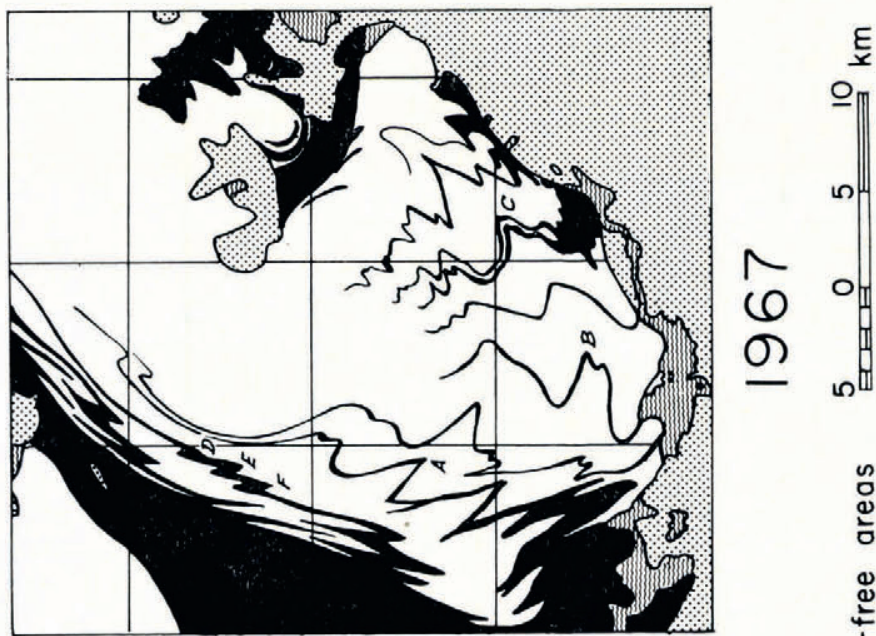

.

3.

कิ

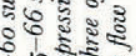

in हो :

กิ영

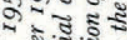

कृष

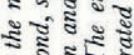

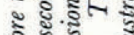

ก)

ข

.ป็

ఖ

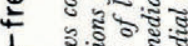

ง :

दीठ

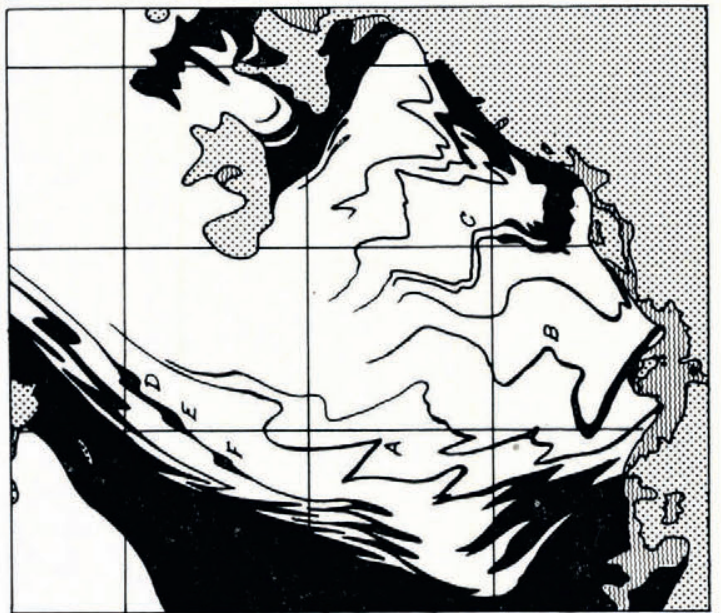

$M$

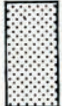

ॠ. इ.

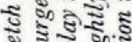

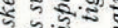

ก त ह हิ

2ิ

है बां का

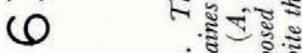

O)

离

-

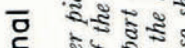

. 돈

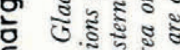

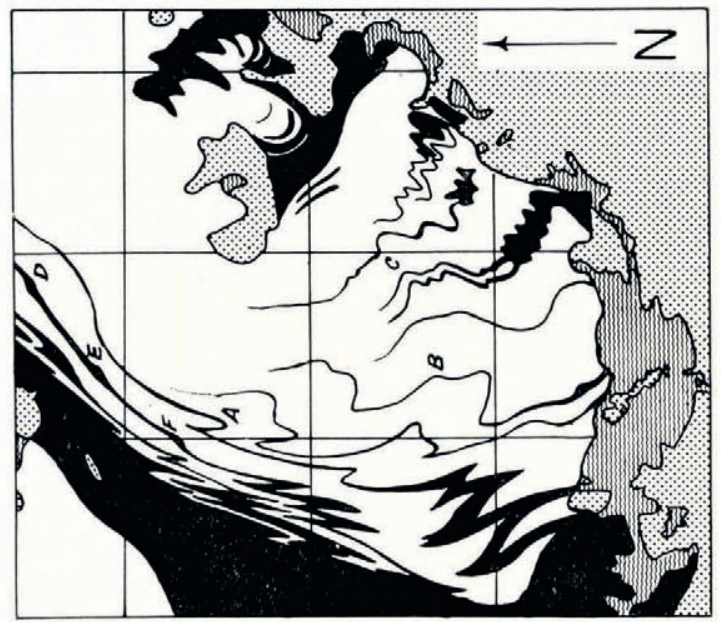

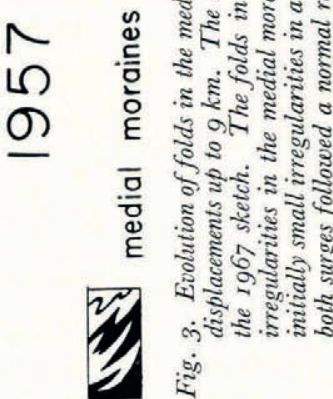




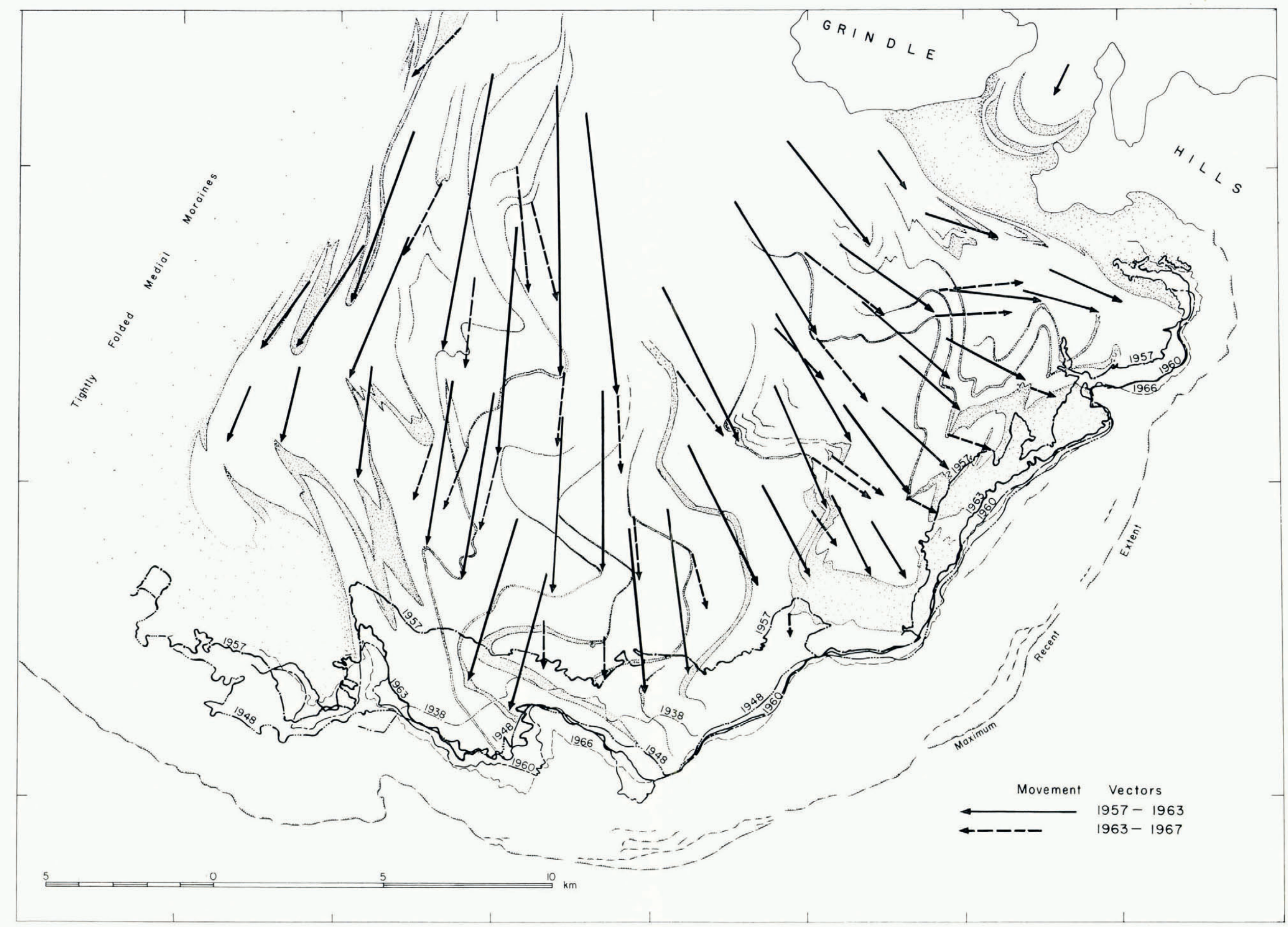

Fig. 4. Map with movement vectors showing the direction and displacement of identifiable debris on Bering Glacier and recent terminal changes. The folded medial moraines are shown in their 1963 positions. Solid arrows denote movement, most of which took place during a surge that ended in 1960 ; the dashed arrows show the displacements which occurred during the smaller $1965-66$ surge.
Note the normal radiating patterns of ice flow; there was no evidence of buckling in the piedmont lobe which would lead to the large folded structures present.

Changes in the terminal position of the glacier demonstrate alternate advances and retreats that are judged to be due to periodic surging. Fragmentary trim lines and terminal moraines are shown. The maximum recent extent of the glacier in recent centuries is from a map by Miller (Ig6r). 
SOURCE OF FOLDS

As ice flow in the piedmont lobe spreads uniformly, what can be the cause of the folded structures present? In seeking their source, it was noted that very similar periodic irregularities in the medial moraines sharply folded. The others take the form of periodic wave-like Grindle Hills and Waxell Ridge (Fig. I). Near the north side of the glacier a medial moraine is present which can be traced to its point of origin where the large branch situated north of Waxell Ridge joins the glacier. Periodic perturbations in this medial band occur that correspond in general shape and spacing to the folds in the same band in the terminal lobe. On the south side of the valley another medial moraine displays very sharp pointed folds that correspond in spacing to those just discussed. Other medial bands, as they become exposed by ablation, have perturbations that bear a direct relationship in spacing to the irregularities in the above medial moraines.
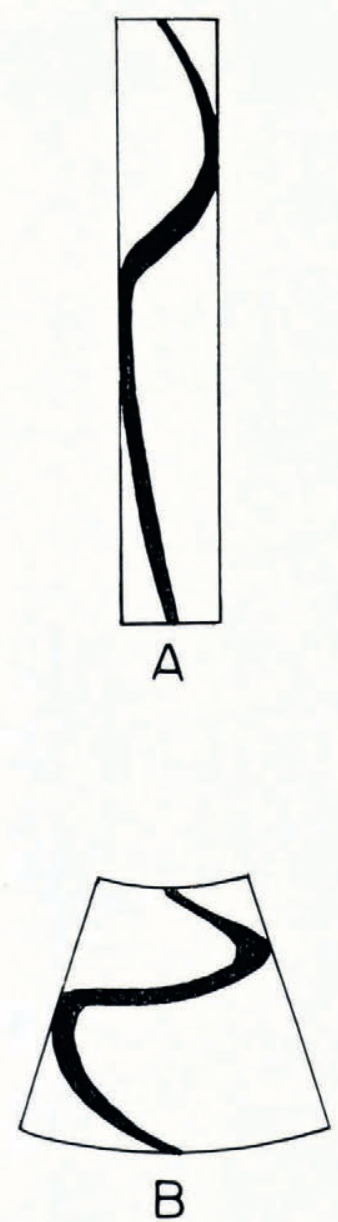

Fig. 5. Two diagrams showing the effects of compressive flow and radial spreading on a surge-modified medial moraine of Bering Glacier. " $A$ " shwes the movement as it appears in the valley section north of the Grindle Hills. " $B$ " shows the same moraine as it uould appear in the terminal lobe. This mechanism may account for the large-scale "accordion" folds of Bering Glacier. Intense marginal shearing would modify similar perturbations in medial moraines to form the greatly attenuated folds such as are located along the big debris band south of the Khitrof Hills. These processes would not necessitate the existence of repeated zones of rapid shear along foliation planes separated by zones of little shear which otherwise might
be required. 


\section{Surge-INDUGed PERTURbations IN MEDial MORAINES}

A clue to the origin of these periodic disturbances is provided by other large valley glaciers that have been observed surging. Typically, the main valley section of these glaciers alternates between near-stagnation between surges and very rapid flow during surges. Some lateral tributaries, however, do not surge, and flow at fairly constant uniform rates. As a result, the ice from these branches pushes out into the slow-moving ice of the main glacier in the interval between its surges, forming conspicuous loops in the medial moraines. These loops are rapidly displaced down the glacier several kilometers during surges. Then, as the main glacier again stagnates, new bulb-shaped loops are formed in the moraines where the tributaries join. Classical examples of these features are displayed by Susitna Glacier (Sharp, I96o, fig. ${ }_{13}$ B) and Muldrow Glacier (Post, I96o, fig. I).

It is judged that the periodic irregularities in the Bering Glacier moraines are due to the same cause. During the r 960 surge the ice in the eastern part of the Bagley Icefield was

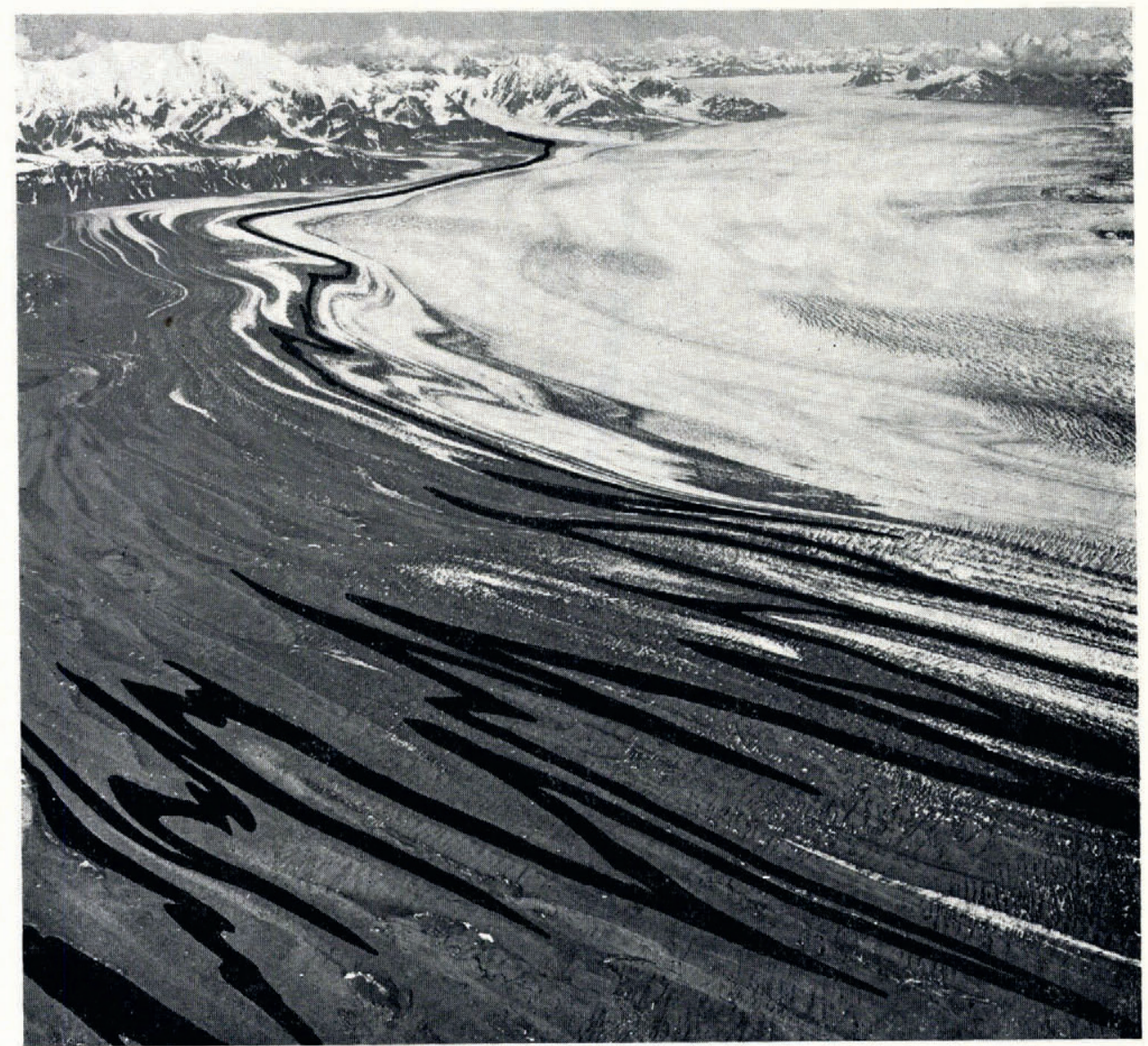

Fig. 6. View north-east up Bering Glacier from over the broad medial band separating Bering and Steller Glacier ice in the terminal lobe. Folded moraines in the foreground originate from tributaries draining the south slopes of Waxell Ridge (top left $t$. Crevassing from the 1957-6o surge shown here discloses the extent of the area where rapid motion took place; few crevasses are present in the heavily moraine-covered ice on the left. In the intermediate region of high marginal shear the greatly attenuated folds are formed (Fig. 3). More than 20 folds have been identified in some of these moraines. For clarity, one medial moraine has been inked. (Photograph by Austin Post, I2 August Ig61.) 
severely crevassed, showing evidence of rapid motion. The large branch north of Waxell Ridge displayed little evidence of abnormal crevassing or increased flow and evidently contributed only a normal amount of ice to the main glacier during the latter's rapid movement. After the surge the main glacier flow was greatly reduced whereas the branch appeared to flow at nearly the same velocity as before. Periodic lateral displacements in the medial band separating these ice streams would thus result from each surge. The similarity in spacing of irregularities in other medial moraines indicates that these are also due to periodic surging of the main glacier past this or other non-surging tributaries.

\section{Evolution of FOLDS}

Except in the terminal lobe, only near the glacier margins are the surge-induced irregularities in the medial moraines sharply folded. The others take the form of periodic wave-like meanders (Fig. I). This form is only slightly modified before the ice spreads out in the terminal lobe. Here, severe radial compressive flow and lateral expansion take place. The diagram in Figure 5 shows show the deformation of these initially small irregularities form large folds such as are present on Bering Glacier.

\section{SHEAR FOLDS}

An extensive area of moraine-covered ice is located in the central part of the Bering Glacier lobe (Fig. I). This material appears to originate from large medial moraines derived from Bering Glacier tributaries located on the southern slopes of Waxell Ridge.

In structure, this debris is composed of several medial moraines intricately folded. These folds are greatly elongated radially and compressed laterally (Fig. 6). The origin of these folds is also judged to be related to the surges. They appear to be formed where medial moraines with initially small periodic lateral perturbations move into the region of extremely high shear along the margin of the glacier. Particularly during surges, the ice in the central part of the main glacier flows rapidly toward the terminus. This carries the part of the moraine situated in the fast-flowing ice past the part nearer the margin which is situated in slow-moving ice. A greatly attenuated fold results. Each lateral irregularity in the medial moraine is subject to this process; as a result the same moraine is repeatedly folded. The evolution of three of these folds in a medial moraine is shown in Figure 3.

\section{SumMARY AND CONCLUSIONS}

The recent surges of Bering Glacier resulted in ice displacements of as much as $13 \mathrm{~km}$ in the terminal lobe. This ice flow followed a normal radial pattern which would not form largescale folds. The large folds present in the medial moraines of the south-eastern part of the lobe are judged to be due to normal lateral spreading and radial compression of periodic irregularities previously emplaced in the moraines by lateral displacements due to periodic surging of the main glacier past non-surging tributaries. The folds in the large central moraine band may result from the deformation of surge-related irregularities in moraines as they move through a marginal zone of high shear.

\section{ACKNOWLEDGEMENTS}

This study was made possible by aerial photographic reconnaissance of glaciers in western North America sponsored by the National Science Foundation between I 960 and r 963 and administered by the University of Washington with Dr P. Church as principal investigator. Photography since 1964 was obtained by the U.S. Geological Survey as a part of glacier studies under the direction of Dr Mark F. Meier.

MS. received I4 Fuly 197 I 


\section{REFERENCES}

Carey, S. W. 1962. Folding. Fournal of the Alberta Society of Petroleum Geologists, Vol. 10, No. 3, p. $95^{-1} 44$.

Meier, M. F., and Post, A. S. 1962. Recent variations in mass net budgets of glaciers in western North America. Union Géodésique et Geophysique Internationale. Association Internationale d'Hydrologie Scientifique. Commission des Neiges et des Glaces. Colloque d'Obergurgl, $10-9-18-91962$, p. $63-77$.

Miller, D. J. I96r. Geology of the Yakataga District, Gulf of Alaska Tertiary province, Alaska. U.S. Geological Survey. Open-file map.

Post, A. S. 1960. The exceptional advances of the Muldrow, Black Rapids, and Susitna Glaciers. Fournal of Geophysical Research, Vol. 65, No. 11, p. 3703-12.

Post, A. S. 1969. Distribution of surging glaciers in western North America. Journal of Glaciology, Vol. 8, No. 53, p. 229-40.

Ramberg, H. 1964. Note on model studies of folding of moraines in piedmont glaciers. Fournal of Glaciology, Vol. 5, No. 38, p. 207-18.

Sharp, R. P. 1958. Malaspina Glacier, Alaska. Bulletin of the Geological Society of America, Vol. 69, No. 6, p. 61 7-46.

Sharp, R. P. 1960. Glaciers. Eugene, Oregon, University of Oregon Press.

Washburn, H. B., and Goldthwait, R. P. 1936. The Harvard-Dartmouth Alaskan Expeditions, 1933-1934. Geographical Fournal, Vol. 87, No. 6, p. 481-517. 